\title{
DNA evidence and miscarriages of justice
}

\author{
Peter Gill
}

DNA analysis has revolutionised forensic science; helping to catch prolific murderers and shining a light on miscarriages of justice that have seen innocent people wrongfully convicted of serious crimes. Such is the power of DNA to identify, convict, and exonerate, that many perceive it to be infallible. Yet DNA evidence has a number of limitations and the costs of not being aware of these can be huge.

Also, in the modern era of DNA profiling, techniques are now so sensitive that routinely detecting minute amounts of DNA is possible - even from just a handful of cells, meaning that DNA may be recovered that is irrelevant to the crime. Once a DNA profile is discovered, it can be used to implicate individuals. Trawling the national DNA database to find a DNA match may be used to wrongly identify individuals. Yet without context, such evidence can be embellished and may be presented in a strongly prosecution biased way [1-4]. The increased sensitivity of forensic DNA techniques therefore makes it even more important for scientists, lawyers and judges to be aware of the limitations of DNA profiling evidence.

Here I describe several proven miscarriages of justice have occurred: contamination; background DNA; secondary transfer and the database trawl. Two examples of dangerous practice are provided: DNA as sole evidence and qualitative reporting.

\section{Context matters}

As forensic DNA techniques have become more and more sensitive, there's an increased chance that DNA recovered from a crime scene is actually: background DNA (deposited before the crime took place and unrelated to it), secondary transfer DNA (DNA from someone who was never there, picked up from them by a handshake or more subtle contact and then left at the crime scene by another individual). Or, as in the case of Adam Scott (below), the result of contamination by an investigator after the crime took place either at the crime scene or laboratory.

The presence of DNA doesn't tell us when or how it got there. There is no date or timestamp and we can't know which body tissue it came from if found in trace amounts. So additional context is needed from other, non-DNA evidence, such as fibres, footwear marks, or fingerprints. When this additional context is ignored, miscarriages of justice can occur

2. A case example of forensic laboratory contamination 
In October 2011, Adam Scott was arrested and charged with raping a woman in Manchester, UK. Swabs of the woman's genitals revealed traces of sperm, and one of these swabs yielded a DNA profile that matched Mr Scott's. This was the only evidence against him. But Mr Scott claimed he was in his home town of Plymouth, UK (more than 200 miles away) at the time of the attack, and had never been to Manchester in his life.

When challenged, the scientist claimed the DNA evidence provided: "strong scientific support for the view that Adam Scott had sexual intercourse with [the victim] rather than he did not." However, this was an error. By itself, a DNA profile can't provide any information about the body fluid it came from, or lead to the inference that sexual intercourse took place. Two months after his arrest, mobile phone records came to light that corroborated Mr Scott's version of events; revealing that his mobile phone had been used in Plymouth a few hours after the reported rape. Finally, after five months in custody, he was released.

A subsequent investigation revealed that Mr Scott had become implicated as a result of accidental contamination of samples within the lab. The day before processing samples from the alleged rape victim, the lab had handled a DNA sample from Mr Scott, following a 'spitting incident' in Exeter, UK. Unfortunately, the disposable plastic plate used to analyse this sample had been inadvertently reused in the rape case, resulting in the misidentification. The true perpetrator was never found.

A second example of contamination which arose in the examination room led to the miscarriage of justice of Farah Jama, Victoria, Australia is described in detail in [2].

\section{A case example of background DNA}

Meredith Kercher was stabbed to death in Perugia, Italy, in 2007, and her flat-mate, Amanda Knox, was a key suspect. A knife retrieved from Ms Knox's boyfriend's flat contained small traces of Ms Kercher's DNA on the blade, and a DNA profile from Ms Knox was recovered from the handle. Prosecutors suggested that the DNA was transferred to the knife when Ms Kercher was stabbed with it, although no blood was detected. Possibly, this was because the knife was cleaned with bleach, they argued. This is a classic example of confirmation bias, a psychological effect where investigators fit the evidence to a presupposed set of circumstances, while ignoring other possibilities. For instance, Ms Knox could have used the knife to cut bread (starch grains were also observed on the blade), and since she lived with Ms Kercher, there was a ready explanation for the presence of her DNA on the knife blade. Methods used to collect and store the evidence were also found to be sub-standard, so the DNA could also have got there through cross-contamination. In the final judgement, the court accepted the defence version of events and exonerated the defendants[5].

\section{A case example of secondary transfer}

When local taxi driver, David Butler's DNA was recovered from the fingernails of murdered sex worker Anne Marie Foy, it seemed like an open and shut case. It was presumed that Ms Foy had torn at his skin as he hit and strangled her, before dumping her body in a park near 
Liverpool city centre in September 2005. The amount of DNA found by police was tiny, but enough to generate a hit against the UK's DNA database, identifying Mr Butler as the source. He denied ever having met the victim, but even though other evidence was lacking, the DNA evidence was enough to see him charged with murder.

However, Mr Butler's defence team queried precisely how that DNA got onto the victim's nails. They established that he was sometimes known by the nickname "flaky", because of the dry skin condition he suffered from, and suggested that perhaps some of his skin cells had transferred to bank notes that were later used to pay Ms Foy - an example of secondary DNA transfer - or through other innocent means[6]. Mr Butler was acquitted.

5. A case example of a database trawl leading to wrongful arrest

In 1999, Raymond Easton, a 49-year-old man from Swindon, UK, was arrested and charged with a burglary in Bolton, UK ( 175 miles away), after a DNA sample from the crime scene matched his DNA profile in the UK national DNA database. Mr Easton was in the advanced stages of Parkinson's disease, and was unable to walk more than ten metres without help. His DNA profile had been loaded onto the database four years earlier following a domestic dispute. The chance of a match was reported as 37-million-to-one [7]. Mr Easton spent several months in custody before his solicitor persuaded police to run further DNA tests, which eliminated him.

As this case clearly highlights, it's crucial to note that a match does not imply identity. Even with a probability as low as one-in-37-million you could find one or more innocent British men in the UK population who would match the crime scene profile described above. The larger the DNA database, the higher the risks of false positive matches, which is why it is essential to consider the non-DNA evidence as well. If this is not done there is a danger that the DNA evidence will be considered out of context and over-weighted by a jury.

6. Dangers of qualitative reporting of complex mixtures

Until recently, in the UK a practice of using verbal strength of evidence based on a subjective assessment of complex DNA mixtures was used in many cases. Often the defendant was identified after a database search. The practice employed the 'matching allele count' (i.e. the number of alleles in the reference that happened to match alleles in the case-stain). Qualitative assessments of strength of evidence e.g. "strong evidence to support..." were provided without a numeric quantitative calculation. Use of the method continued even though it was discredited in the literature $[8,9]$, the Dlugosz et al judgement [10] paradoxically supported the practice and this appeared to be more influential than the opposing scientific literature.

Recently, the UK regulator issued guidance that recommended qualitative reporting to be discontinued "because it is potentially prejudicial". The question remains what to do with 
cases already reported using an unreliable method as highlighted in a Times newspaper article dated 2014 [11]

7. The problem of DNA as sole evidence

The following is not a proven miscarriage of justice: In R v. Tsekiri [12], the defendant was found guilty of burglary. The only evidence was presence of DNA (mixture) on a door handle, and the court acknowledged: "the finding of DNA attributable to a defendant at the scene of a crime was the sole evidence against a defendant". The case is analysed in [1]. When a jury is provided with a figure of 1 billion, of course the evidence may appear to be compelling, supporting the prosecution case. It is possible that in this example, the jury is being led down the path of findings biased interpretation because the word 'match' implies 'identity'. There appears to have been no advice in the judgement what to do with this figure of 1 billion. The word 'match' invites the prosecutor's fallacy as laypersons can easily believe that a 'match' is synonymous to 'identification' [13]. There is the implicit risk of confirmation bias where evidence inconvenient to the prosecution is ignored or underweighted [2] and there is the associated danger that apparently compelling 'evidence' may be used to infer the activity (i.e. the act of touching the door handle). It is bizarre that the judgement directing contradicts the Crown Prosecution Guidance itself which recognises the dangers and states:

"The danger in placing too much reliance on the findings of experts is demonstrated in a series of cases in relation to DNA analysis, where there was no other evidence against the accused save the presence of his DNA found at the scene of a crime. The Court of Appeal has emphasised that expert evidence can only be judged in the light of the other evidence in the case. In these cases, the absence of any other evidence, however limited, should have been fatal to the case being charged."

\section{Conclusion}

It would be naïve to believe that the miscarriages of justice described were isolated incidents. Once identified, studies have revealed a particular, prosecution biased way of thinking about evidence that is sadly prevalent. The main concern is that the 1 in 1 billion DNA statistic is carried over to the activity level (which is a completely different statistic that has nothing to do with strength of evidence of the DNA 'match'). See review by Champod [14] who explains the dangers of not properly considering evidence at the activity level.

Although there is a relatively well developed scientific framework (see comprehensive ENFSI guidelines [4]), there is an obvious barrier to communication with judges, lawyers and investigators, as the recent 2017 case of R. v. Tsekeri demonstrates. There is a need for education at all levels of the criminal justice system. It is clear that the cases discussed above should be filtered out at the investigative stage so that they never actually proceed to 
court, but once prosecutors have decided that there is sufficient evidence, then the court needs to provide a forum where the evidence may be properly examined and challenged. Defence experts will need equivalent resources and training in order to conduct fair and thorough examinations.

9. References

[1] P. Gill, T. Hicks, J.M. Butler, E. Connolly, L. Gusmao, B. Kokshoorn, N. Morling, R.A.H. van Oorschot, W. Parson, M. Prinz, P.M. Schneider, T. Sijen, D. Taylor, DNA commission of the International society for forensic genetics: Assessing the value of forensic biological evidence Guidelines highlighting the importance of propositions: Part I: evaluation of DNA profiling comparisons given (sub-) source propositions, Forensic Sci Int Genet 36 (2018) 189-202.

[2] P. Gill, Misleading DNA evidence: Reasons for miscarriages of justice, Elsevier, London, 2014. [3] Making Sense of Forensic Genetics, Sense about Science http://senseaboutscience.org/wpcontent/uploads/2017/01/Making-Sense-of-Forensic-Genetics.pdf (2017).

[4] ENFSI, ENFSI Guideline for evaluative reporting in forensic science: Strengthening the evaluation of forensic results across Europe (STEOFRAE)

https://www.unil.ch/esc/files/live/sites/esc/files/Fichiers\%202015/ENFSI\%20Guideline\%20Evaluativ e\%20Reporting, (2015).

[5] P. Gill, Analysis and implications of the miscarriages of justice of Amanda Knox and Raffaele Sollecito, Forensic Science International: Genetics 23 (2016) 9-18.

[6] http://www.telegraph.co.uk/news/science/9115916/The-case-against-DNA.html.

[7]

http://www.heraldscotland.com/news/12440889.Guilty by a handshake Crime scene DNA /. [8] P. Gill, O. Bleka, T. Egeland, Does an English appeal court ruling increase the risks of miscarriages of justice when complex DNA profiles are searched against the national DNA database?, Forensic Sci Int Genet 13 (2014) 167-75.

[9] I. Evett, S. Pope, Science of mixed results. Law Soc. Gaz. Available online at:

http://www.lawgazette.co.uk/5036961.article

(2013).

[10] R v Dlugosz, Pickering MDS (2013). Court of Appeal of England and Wales (Criminal Division), EWCA Crim 2. Available online at: http://www.bailii.org/ew/cases/EWCA/Crim/2013/2.html, (2013). [11] https://www.thetimes.co.uk/article/convictions-at-risk-as-home-office-admits-errors-in-dnaevidence-nx95xsw026x.

[12] Tsekiri, R v [2017] EWCA Crim 40 (17 February 2017)

[13] W.C. Thompson, E.J. Newman, Lay understanding of forensic statistics: Evaluation of random match probabilities, likelihood ratios, and verbal equivalents, Law Hum Behav 39(4) (2015) 332-49.

[14] C. Champod, DNA transfer: informed judgment or mere guesswork?, Front Genet 4 (2013) 300. 